\title{
MENINGKATKAN MINAT BELAJAR SISWA MELALUI LAYANAN BIMBINGAN KELOMPOK TEKNIK TOKEN ECONOMY
}

\author{
Maria Ulfa, ${ }^{1}$ Ria Safaria Sadif, ${ }^{2}$ La Hanu ${ }^{3}$ \\ Email: ulfa.razak88@gmail.com ${ }^{1}$ \\ Bimbingan dan Konseling, FKIP-UM. Buton ${ }^{1,2}$ \\ Fakultas Ekonomi, Universitas Negeri Medan ${ }^{3}$
}

\begin{abstract}
Abstrak
Faktor sosial dan non sosial merupakan salah satu yang membentuk rendahnya minat belajar pada diri siswa di SMP Negeri 5 Wangi-wangi. Guru sangat berperan terhadap pembentukan perkembangan siswa. Dalam hal ini, peneliti memilih layanan bimbingan kelompok melalui teknik token economy untuk meningkatkan minat belajar siswa. Tujuan penelitian ini untuk mengetahui dan mendeskripsikan layanan bimbingan kelompok dengan teknik token economy untuk meningkatkan minat belajar siswa. Metode penelitian yang digunakan adalah pendekatan penelitian kuantitatif dengan desain penelitian kuantitatif metode eksperimen pre-experimental dengan desain one group pretest posttest. Adapun populasi dalam penelitian ini adalah siswa kelas VIII SMP Negeri 5 Wangi-wangi melalui teknik sampling pupossive dengan sampel penelitian 14 siswa yang memiliki minat belajar rendah. Berdasarkan hasil penelitian dan analisis data diperoleh kesimpulan: (1) secara umum, tingkat minat belajar siswa kelas VIII SMP Negeri 5 Wangi-wangi menunujukkan bahwa 5 siswa atau 35.7.\% subyek memiliki minat belajar pada kategori sedang, dan 9 siswa atau $64.3 \%$ subyek memiliki minat belajar yang tinggi, sehingga dapat disimpulkan bahwa pemberian perlakuan melalui teknik token economy dapat meningkatkan minat belajar siswa.; (2) ada perbedaan yang signifikan antara hasil pretest dengan posttest dengan nilai masing-masing nilai sig. (2-tailed) probabilitas 0,001 pada taraf signifikansi nilai $0.05(\mathrm{p}<0.05)$, yang berarti dapat disimpulkan bahwa pemberian perlakuan melalui teknik token economy untuk meningkatkan minat belajar siswa yang dilakukan berhasil secara signifikan atau efektif untuk dilakukan.
\end{abstract}

Kata kunci: Token Economy; Minat Belajar; Bimbingan Kelompok

\begin{abstract}
Social and non-social factors are one that forms the low interest in learning in students in Wangi-Wangi 5 Middle School. The teacher is very instrumental in shaping the development of students. In this case, the researcher chose group guidance services through token economy techniques to increase student interest in learning. The purpose of this research is to find out and describe group guidance services with token economy techniques to increase student interest in learning. The research method used is a quantitative research approach with a quantitative research design pre-experimental experimental method with one group pretest posttest design. The population in this study were eighth grade students of SMP Negeri 5 Wangi-wangi through pupossive sampling technique with a sample of 14 students who had low learning interest. Based on the results of research and data analysis concluded: (1) in general, the level of interest in learning for students of class VIII of SMP Negeri 5 Wangi-wangi showed that 5 students or 35.7\% subjects had interest in learning in the medium category, and 9 students or $64.3 \%$ subjects have a high interest in learning, so it can be concluded that giving treatment through token economy techniques can increase student interest in learning; (2) there is a significant difference between the results of the pretest and posttest with the value of each sig. (2-tailed) probability of 0.001 at a significance level of value of $0.05(p<0.05)$, which means that it can be concluded that the administration of treatment through token economy techniques to increase student interest in learning is done successfully significantly or effectively to be carried out
\end{abstract}

Keyword: Token Economy; Interest To Learn; Group Counseling

\section{PENDAHULUAN}

Di era teknologi digital dan revolusi 4.0 ini, pendidikan diharapkan dapat menghasilkan perubahan yang dapat mengembangkan suatu bangsa. Pendidikan merangsang kreativitas seseorang agar sanggup untuk maju menghadapi perubahan dan perkembangan zaman. Hal tersebut dikaitkan dengan peningkatan mutu pendidikan di sekolah terkhusus dalam meningkatkan minat belajar siswa yang 
berdampak pada sikap dan perilaku siswa dalam mengikuti pelajaran di kelas. Faktor sosial dan non sosial merupakan salah satu pembentuk rendahnya minat belajar siswa.

Minat belajar siswa adalah perasaan senang, suka dan perhatian terhadap usaha untuk mendapatkan ilmu pengetahuan. Dalam kegiatan belajar, siswa di sekolah mempelajari berbagai ilmu pengetahuan dan diusahakan agar semua siswa mendapatkan nilai yang bagus yg tentunga dapat dicapai dengan memiliki minat belajar yang tinggi (Astuti, 2015, p.71). Minat memiliki peranan yang sangat penting dalam kehidupan siswa dan mempunyai dampak yang besar terhadap sikap dan prilaku. Siswa yang berminat terhadap kegiatan belajar akan berusaha lebih keras dibandingkan siswa yang kurang berminat dengan belajar (Riwahyudin, 2015).

Siswa yang memiliki minat belajar yang tinggi akan cenderung tekun, ulet, semangat dalam belajar, pantang menyerah, dan senang menghadapi tantangan, sedangkan siswa yang memiliki minat belajar yang rendah umumnya akan malas belajar dan cenderung menghindar dari tugas yang diberikan guru, senang jika guru tidak hadir, dan tidak ada upaya belajar mandiri (Yanti, Trisoni, dan Fajar, 2018). Sikap menunjukkan besarnya keyakinan seseorang terhadap dirinya bahwa dia mampu menyelesaikan segala sesuatu dengan kemampuan dirinya. Dari hal tersebut dapat diketahui bahwa sikap, sebagai faktor internal dalam diri siswa yang berpengaruh terhadap minat yang menunjukkan besarnya keingintahuan siswa terhadap apa yang mereka pelajari (Riwahyudin, 2015).

Berkaitan dengan hal tersebut, fenomena yang terjadi di SMP Negeri 5 Wangi-wangi adalah rendahnya minat belajar siswa di kelas VIII. Hal tersebut terlihat saat proses pembelajaran berlangsung. Secara fisik siswa dalam keadaan sehat, akan tetapi siswa kurang semangat dalam mengikuti proses pembelajaran di kelas. Selain itu, siswa juga merasa kemampuan berpikirnya (IQ) tidak mampu untuk mengikuti pelajaran, ditambah dengan sikap yang memang membentuk minat belajarnya semakin rendah seperti siswa semau-maunya mengikuti proses pembelajaran di kelas, dan bahkan ada beberapa siswa yang bertahan berada di kelas namun hanya sekedar meramaikan kelas tidak memperhatikan proses pembelajaran. Faktor sosial dan non sosial juga membentuk rendahnya minat belajar pada diri siswa. Seperti yang terjadi di kelas 
VIII SMP Negeri 5 Wangi-wangi yaitu pergaulan dari siswa-siswa tersebut. Beberapa siswa tersebut memang bergaul pada lingkungan yang kurang kondusif. Disamping itu, sarana dan prasana dalam proses pembelajaran juga kurang memadai untuk mengajar kurang mendukung. Ditambah lagi pendekatan atau metode pembelajaran guru yang sangat monoton menjadikan siswa-siswa jenuh dan kurang berminat dalam belajar.

Hasil wawancara peneliti dengan guru-guru di sekolah tersebut, diperoleh informasi bahwa hasil belajar siswa masih rendah, siswa kurang berminat untuk aktif dalam proses pembelajaran. Selain itu, siswa cenderung malas untuk memperhatikan pelajaran dikarenakan kurangnya perhatian dari keluarga dan lingkungan. Pada akhirnya dari faktorfaktor tersebut di atas siswa menjadi kurang senang, kurang tertarik, tidak memperhatikan guru dan bahkan tidak ingin terlibat dalam proses belajar.

Dalam meningkatkan minat belajar siswa, beberapa pendekatan atau teknik konseling dilakukan. Salah satunya dengan menggunakan teknik token economy. Teknik ini dapat diimplementasikan dalam bentuk konseling kelompok dengan pemberian reward atau hadiah yang bermanfaat bagi siswa dan dapat meningkatkan minat belajar siswa. Oleh karena itu, penggunaan teknik token ecomony diharapkan dapat meningkatkan minat belajar siswa. Dengan adanya hal tersebut, peneliti menggunakan teknik token economy untuk meningkatkan minat belajar siswa kelas VIII SMP Negeri 5 Wangi-wangi.

Token economy sebagai salah satu teknik modifikasi perilaku, dalam pelaksanaannya didasarkan pada pendekatan perilaku yang menggunakan penguatan positif (Erford, 2016: 395). Teknik token economy menekankan pada pemberian penghargaan yang bertujuan untuk memotivasi siswa agar berperilaku sesuai dengan yang diharapkan. Token economy merupakan salah satu teknik dalam memodifikasi perilaku dengan cara pemberian satu kepingan (satu tanda, satu isyarat) sesegera mungkin setiap kali setelah perilaku sasaran muncul. Tokentoken tersebut dikumpulkan dan kemudian dalam jangka waktu tertentu dapat ditukarkan dengan hadiah atau sesuatu yang mempunyai makna. Singkatnya token economy merupakan sebuah penguatan untuk perilaku yang dikelola dan diubah, seseorang dapat menerima penguatan untuk meningkatkan atau mengurangi perilaku yang diinginkan (Purwanta, 2015: 148). 
Penggunaan teknik token economy dapat meningkatkan kedisiplinan siswa, hal tersebut ditandai dengan meningkatnya kualitas proses pembelajaran (Nimas R, 2015). Teknik token economy juga dapat meningkatkan kemandirian pada anak-anak (Chotim, M. 2016). Disamping itu teknik token economy diterapkan untuk menurunkan durasi bergurau dan frekuensi mengangkat tangan. Terjadi perubahan perilaku yang signifikan antara kondisi baseline dan intervensi dalam penggunaan teknik ini (Hapsari, AM, 2017).

Berdasarkan studi awal yang dilakukan sebelumnya, penggunaan teknik token economy telah banyak ditemui. Namun penelitian mengenai penerapan teknik token economy untuk meningkatkan minat belajar siswa masih belum banyak dilakukan dan ditemukan baik secara pustaka maupun online (internet). Oleh sebab itu, penelitian tentang meningkatkan minat belajat siswa melalui layanan bimbingan kelompok teknik token economy ini dilakukan. Adapun tujuan dari penelitian ini adalah untuk mengetahui dan mendeskripsikan efektivitas layanan bimbingan kelompok untuk meningkatkan minat belajar siswa kelas VIII SMP Negeri 5 Wangi-wangi Kabupaten Wakatobi.

\section{METODE PENELITIAN}

Pendekatan penelitian yang digunakan dalam penelitian ini adalah pendekatan kuantitaif. Penelitian ini adalah peneliitian eksperimen. Desain penelitian yang digunakan adalah pre eksperimental dengan one group pretestposttes design yaitu suatu teknik untuk mengetahui efek sebelum diberikan dan sesudah perlakuan. Desain eksperimen ini, tidak menggunakan variabel kontrol dan sampel tidak pilih secara random. Penelitian ini dilaksanakan pada 4 Maret sampai 18 Mei 2019 di SMPN 5 Wangiwangi Wakatobi tahun akademik 2018/2019. Berikut tabel desain penelitian one group pretest-posttes design

Tabel. 1. One Group Pretest-Posttest Design

\begin{tabular}{ccc}
\hline Tes Awal & Perlakuan & Tes Akhir \\
\hline O1 & $\mathrm{X}$ & $\mathrm{O} 2$ \\
\hline
\end{tabular}

Berdasarkan tabel 1 di atas dapat dijelaskan bahwa $\mathrm{O} 1$ merupakan tes awal (pre-test) dilakukan sebelum penerapan teknik token economy melalui bimbingan kelompok, $\mathrm{X}$ adalah perlakuan (treatment) penerapan teknik token economy melalui bimbingan kelompok, dan O2 merupakan tes akhir (Post-test) dilakukan setelah penerapan teknik token economy melalui bimbingan kelompok. 
Populasi dalam penelitian ini, siswa kelas VIII SMP Negeri 5 Wangi-wangi dan sampel dalam penelitian ini menggunakan teknik non probability sampling yaitu teknik pengambilan sampel yang tidak memberikan peluang yang sama bagi setiap unsur (anggota) populasi untuk dipilih menjadi sampel (Sugiyono 2013: 122). Sampel dalam penelitian ini menggunakan sampling purposive yaitu teknik pengambilan sampel yang yang ditentukan oleh peneliti karena tujuan khusus tertentu (Arikunto, 2012). Jumlah sampel adalah 14 siswa dengan memilih siswa yang memiliki minat belajar yang rendah.

Teknik pengumpulan data yang digunakan dalam penelitian ini adalah berupa alat Rencana Pelaksanaan Layanan Bimbingan dan Konseling (RPL), lembar observasi pengamatan token, dan skala sikap. Rencana Pelaksanaan Layanan (RPL) Bimbingan dan Konseling adalah seperangkat alat pembelajaran yang disediakan oleh guru Bimbingan dan konseling (Konselor) sebelum memulai pemberian layanan yang berisi tentang layanan bimbingan, konseling, dan informasi. Konselor menyampaikan materi atau bahan ajar yang sesuai dengan isi RPL. Lembar observasi pengamatan token merupakan lembar observasi yang digunakan untuk mengamati minat belajar siswa sesuai dengan indikator dengan memberikan tanda ceklist ketika siswa telah melaksanakan sesuatu hal. Adapun skala yang akan digunakan merupakan skala model Likert. Skala yang digunakan dalam teknik penelitian ini yaitu, skala minat belajar. Skala disusun dengan empat alternatif jawaban yaitu SS (Sangat Sesuai), S (Sesuai), TS (Tidak Sesuai), dan STS (Sangat Tidak Sesuai). Tahapan pengumpulan data dilakukan dengan meminta subyek penelitian memberikan respon jawaban pada skala. Hasil dari jawaban subyek dilakukan penyekoran untuk aitem favourable (mendukung) jawaban SS diberi skor 4, S diberi skor 3, TS diberi skor 2, dan STS diberi skor 1, sedangkan aitem unfavourable (tidak mendukung) jawaban SS diberi skor $1, \mathrm{~S}$ diberi skor 2, TS diberi skor 3, dan STS diberi skor 4. Analisis data dalam perhitungan skala ini menggunakan bantuan SPSS 21. For windows. Berikut hasil deskripsi data skala minat belajar. Tabel 2. Hasil Deskripsi Minat Belajar

\begin{tabular}{lcc}
\hline \multicolumn{1}{c}{ Deskripsi } & \multicolumn{2}{c}{ Skor } \\
\cline { 2 - 3 } & Pretest & Postest \\
\hline Skor Maksimal & 75 & 85 \\
Skor Minimal & 42 & 58 \\
Mean & 58.8 & 66.64 \\
Standar Deviasi & 11.14 & 6.16 \\
Emperik skor & & \\
Maksimal & 96 & 24 \\
\hline
\end{tabular}




\begin{tabular}{ccccc}
\hline $\begin{array}{c}\text { Emperik } \\
\text { Minimal }\end{array}$ & & & 96 & 24 \\
\hline Tabel & 2 & di & atas & menunjukkan
\end{tabular}

adanya perbedaan hasil pretest dan posttest pada skor maksimal dan skor minimal. Hasil tersebut menunjukkan adanya peningkatan yang signifikan setelah diberikan perlakuan dengan melalui layanan bimbingan kelompok dengan teknik token economy.

Bimbingan kelompok teknik token economy yang dimaksud dalam penelitian ini adalah pemberian bantuan kepada siswa kelas VIII SMP Negeri 5 Wangi-wangi yang kurang berminat, kurang tertarik, dan tidak ingin terlibat dalm proses belajar secara kelompok dengan bantuan berupa teknik modifikasi perilaku dengan cara pemberian token atau kepingan untuk menguatkan perilaku positif. Token ini berupa poin, cek, lubang di kartu, kupon, chip, uang mainan, tanda bintang atau apapun yang bisa dengan mudah diidentifikasi sebagai milik siswa. Token ini bisa ditukar dengan benda atau aktivitas pengukuh yang sering disebut pengukuh idaman (hadiah).

Adapun minat belajar yang dimaksud dalam penelitian ini adalah suatu Kecenqerungan siswa Keıas vılı SMP Negeri 5 Wangi-wangi untuk memiliki rasa senang tanpa ada paksaan sehingga dapat menyebabkan perubahan pengetahuan, ketrampilan dan tingkah laku. Minat belajar siswa diketahui dengan menerapkan dalam skala sikap minat belajar melalui penerapan aspekaspek meliputi perasaan senang siswa, ketertarikan siswa, perhatian siswa dan keterlibatan siswa dalam mengikuti proses pembelajaran.

Teknik analisis data yang digunakan adalah statistik data kuantitatif dengan menggunakan perhitungan statistik statistik non parametrik yAdapun teknik perhitungan dengan menggunakan uji Wilcoxon Signed Rank test. Dalam upaya mengetahui efektivitas bimbingan kelompok melalui teknik token economy untuk meningkatkan minat belajar siswa kelas VIII SMP Negeri 5 Wangi-wangi, teknik analisis data dalam penelitian ini menggunakan bantuan SPSS 21. for windows.

\section{HASIL DAN PEMBAHASAN}

Berdasarkan validasi item-item dalam skala sikap minat belajar, dari 24 pernyataan yang diuji coba, dinyatakan valid atau memenuhi kriteria. Berikut disajikan tabel hasil analisis reliabilitas.

Tabel 3. Hasil Reliabilitas Skala Minat Belajar

\begin{tabular}{cc}
$\begin{array}{c}\text { Cronbach's } \\
\text { Alpha }\end{array}$ & N of Items \\
\hline 930 & 24 \\
\hline
\end{tabular}


Berdasarkan hasil pengujian validitas dan reliabilitas pada tabel 3 di atas menggunakan teknik alpha Cronbach, diketahui bahwa indeks reliabilitas skala minat belajar sebesar 0,930 dengan jumlah item keseluruhan 24 item, berarti skor skala tersebut mampu mencerminkan $93 \%$ dari variasi yang terjadi pada skor murni kelompok subyek yang bersangkutan, dengan kata lain bahwa 7\% dari perbedaan skor yang tampak akibat variasi error atau kesalahan pengukuran.

Tabel 4. Hasil Uji Wilcoxon

\begin{tabular}{|c|c|c|c|c|}
\hline & & N & lean Rank & Sum of Ranks \\
\hline \multirow{4}{*}{$\begin{array}{l}\text { POST. } \\
\text { PRETEST }\end{array}$} & Negative Ranks & $0^{a}$ & .00 & .00 \\
\hline & Positive Ranks & $14^{b}$ & 7.50 & 105.00 \\
\hline & Ties & $0^{c}$ & & \\
\hline & Total & 14 & & \\
\hline $\begin{array}{l}\text { a PPST < PRETEST } \\
\text { b.POST P PRETST } \\
\text { c.POST = PRETEST }\end{array}$ & & & & \\
\hline
\end{tabular}

Tabel 4 di atas, dengan jumlah 14 sampel penelitian, diperoleh hasil Negative Rank atau selisih (negatif) antara hasil pretest dan posttest minat belajar siswa adalah 0 , baik itu pada nilai N, Mean Rank dan Sum of Rank. hal tersebut berarti, nilai 0 ini menunjukkan tidak adanya penurunan (pengurangan) dari hasil pretest ke posttest. Positive Rank atau selisih (positif) antara hasil pretest dan posttest minat belajar siswa adalah 14 artinya ada 14 siswa yang mengalami peningkatan minat belajar dengan teknik token economy dari hasil pretest dan posttest. Mean Rank atau ratarata peningkatan tersebut adalah 7.50, sedangkan jumlah rangking positif atau Sum of Rank adalah sebesar 105,00. Ties dalam tabel 3 di atas menunjukkan kesamaan nilai pretest dan posttest. Dalam hal ini ties menunjukkan angka 0 , sehingga dapat disimpulkan bahwa tidak ada nilai yang sama antara pretest dan posttest.

Kategorisasi pada variabel dengan menetapkan kriteria kategori yang didasari oleh suatu asumsi bahwa subyek dalam populasi terdistribusi menurut model normal, untuk mengetahui tinggi rendahnya skor yang diperoleh subyek dapat dilakukan pengkategorisasian dengan menerapkan suatu kriteria. Skor yang diperoleh subyek diklarifikasikan menggunakan 3 kategori yaitu rendah, cukup, dan tinggi. Kriteria kategorisasi didasarkan pada standar deviasi dan mean hipotetik (Azwar, 2012). Kategorisasi yang akan digunakan adalah katgorisasi jenjang berdasarkan distribusi normal. Norma kategorisasi skor dapat dilihat pada tabel berikut.

Tabel 5. Norma Kategorisasi

\begin{tabular}{cl}
\hline Interval kategorisasi & \multicolumn{1}{c}{$\begin{array}{c}\text { Norma } \\
\text { kategorisasi }\end{array}$} \\
\hline$X<(\mu-1,0 \delta)$ & Rendah \\
$(\mu-1,0 \delta) \leq X<(\mu+1,0 \delta)$ & Sedang
\end{tabular}


$(\mu+1,0 \delta) \leq \mathrm{X}$

Tinggi

Keterangan:

X : Skor skala

$\delta \quad:$ Standar deviasi

$\mu \quad$ : Mean/rerata

Kategorisasi pada tabel 5 tersebut didasarkan pada nilai mean hipotetik dan standar hipotetik masing-masing variabel yang dapat dilihat pada tabel berikut ini.

Tabel 6. Kategorisasi Minat Belajar

\begin{tabular}{rcccc}
\hline & Interval & Frekuensi & $\%$ & Kategorisasi \\
\hline \multirow{2}{*}{$\begin{array}{r}\text { Pretest } \\
\text { minat } \\
\text { belajar }\end{array}$} & $X<48$ & 14 & 100 & Rendah \\
\cline { 2 - 5 } & $48 \leq X<72$ & & & Sedang \\
\cline { 2 - 5 } & $72 \leq X$ & & & Tinggi \\
\cline { 2 - 5 } $\begin{array}{r}\text { Posttest } \\
\text { minat }\end{array}$ & Total & $\mathbf{1 4}$ & $\mathbf{1 0 0}$ & \\
\cline { 2 - 5 } belajar & $48 \leq X<48$ & - & & Rendah \\
\cline { 2 - 5 } & $72 \leq X$ & 9 & 64.3 & Tinggi \\
\cline { 2 - 5 } & Total & $\mathbf{1 4}$ & $\mathbf{1 0 0}$ & \\
\hline
\end{tabular}

Berdasarkan tabel 6. di atas kategorisasi pretest menunjukkan dari 14 siswa, 14 siswa atau $100 \%$ subyek dalam kategori memiliki minat belajar yang rendah. Jumlah 14 sampel inilah yang peneliti gunakan dalam penelitian dengan menerapkan teknik token economy. Hasil kategorisasi posttest, pada tabel 6 tersebut menunjukkan adanya peningkatan yang cukup signifikan. Berdasarkan tabel 6 di atas, dijelaskan bahwa dari 15 sampel penelitian, minat belajar meningkat pada kategori sedang sebanyak 5 siswa atau $35.7 \%$ dan pada kategori tinggi sebesar 9 siswa atau $64.3 \%$ subyek telah memiliki minat belajar yang tinggi atau baik. Sehingga dapat disimpulkan bahwa pemberian perlakuan berupa teknik token economy dapat meningkatkan minat belajar siswa. Berikut diagram perbedaan hasil pretest dan posttest skala sikap minat belajar siswa sebelum dan setelah diberi perlakuan

Grafik 1. Perbandingan Hasil Pretest Dan Posttest

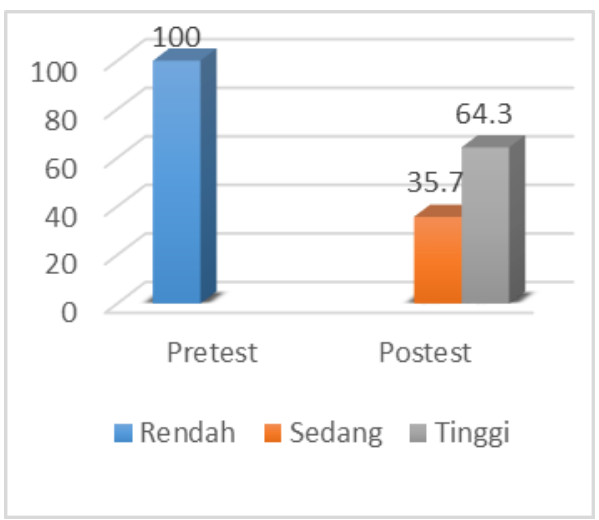

Berdasarkan grafik 1. tersebut di atas menunjukkan bahwa ada perbedaan yang signifikan antara hasil pretest dan posttest untuk meningkatkan minat belajar siswa pada kelas VIII SMP Negeri 5 Wangi-wangi dengan menerapkan layanan bimbingan kelompok melalui teknik token economy. Hasil posttest tersebut menunjukkan bahwa teknik token economy dapat meningkatkan minat belajar siswa.

Hal tersebut menunjukkan bahwa sebagian siswa kelas VIII SMP Negeri 5 Wangi-wangi memiliki tingkat minat belajar yang masih kurang atau secara persentase dalam kategori rendah, karena alasan tersebut dalam penelitian ini diberikan layanan bimbingan kelompok dengan maksud bahwa layanan 
bimbingan kelompok memiliki fungsi dua utama yaitu (1) pemahaman, agar siswa memiliki pemahaman terhadap dirinya (potensi) dan lingkungannya. Dalam hal ini konseli diharapkan mampu mengembangkan potensi dirinya secara optimal, dan menyesuaikan dirinya dengan lingkungan secara dinamis dan konstruktif. Fungsi (2) yaitu pengembangan yang bersifat lebih proaktif. Konselor menciptakan lingkungan belajar yang kondusif, yang memfasilitasi perkembangan konseli. Konselor dan personel sekolah lainnya secara sinergi sebagai teamwork berkolaborasi atau bekerjasama merencanakan dan melakasanakn program bimbingan secara sistematis dan berkesinambungan dalam upaya membantu konseli mencapai tugas-tugas perkembangannya.

Berdasarkan hasil pretest tersebut menunjukkan minat belajar siswa masih perlu ditingkatkan melalui aspek-aspek minat belajar menurut Slameto (2013), yang diterapkan dalam penelitian ini, berdasarkan hasil pengamatan menurut aspek-aspek tersebut dijabarkan sebagai berikut:

1) Perasaan Senang

Seorang siswa yang memiliki perasaan senang atau suka terhadap suatu mata pelajaran.
Sebelum diberikan perlakuan melalui bimbingan kelompok teknik token economy, siswa belum memiliki perasaan senang untuk mengikuti pelajaran. Hal tersebut tampak melalui perilaku siswa seperti terpaksa mengikuti pelajaran karena takut jika kena sanksi dari sekolah atau ketahuan oleh orangtua di rumah.

2) Ketertarikan Siswa

Berhubungan dengan daya gerak yang mendorong untuk cenderung merasa tertarik pada orang, benda. Sebelum pemberian perlakuan dengan teknik token economy, siswa belum menampakkan ketertarikan dirinya untuk mengikuti pelajaran disebabkan karena penggunaan metode guru dalam mengajar monoton dan membosankan.

3) Perhatian Siswa

Perhatian merupakan konsentrasi atau aktivitas jiwa terhadap pengamatan dan pengertian, dengan mengesampingkan yang lain dari pada itu. Sebelum penerapan teknik token economy, siswa belum memiliki minat pada mata pelajaran karena menganggap sulitnya mata pelajaran yang diajarkan oleh guru dan sistem 
pemberian tugas yang tidak menarik atau memotivasi.

4) Keterlibatan Siswa

Ketertarikan seseorang akan suatu objek yang mengakibatkan orang tersebut senang dan tertarik untuk melakukan atau mengerjakan kegiatan dari objek tersebut. Sebelum penerapan teknik token economy, yang tampak adalah siswa bermalas-malasan untuk aktif dalam proses belajar. Siswa hanya sekadar mengikuti pelajaran atau memformalitaskan diri untuk ikut belajar akan tetapi tidak aktif di kelas.

Jika dilihat dari aspek-aspek minat belajar yang diterapkan dalam skala sikap yaitu (1) perasaan senang, ketertarikan siswa, (3) perhatian siswa dan (4) keterlibatan siswa, hal-hal tersebut telah sesuai dengan yang dijalani dan dirasakan oleh siswa. Keberhasilan siswa dalam memahami dan mengembangkan minat belajarnya tergantung pada kemampuan siswa untuk mengolah dan memanaj minat belajarnya. Minat belajar sangat berkaitan erat dengan prestasi dan motivasi belajar karena pada dasarnya motivasi belaja merupakan faktor yang mempengaruhi minat belajar (Prahmadita, 2014: 12)
Tabel 6. Hasil Analisis Tes Statistik Wilcoxon

\begin{tabular}{lcc}
\hline Kelompok & Z & $\begin{array}{c}\text { Asymp. Sig. (2- } \\
\text { tailed) }\end{array}$ \\
\hline Pretest- & $-3.298^{\mathrm{b}}$ & 0.001 \\
Postest & & \\
\hline
\end{tabular}

Berdasarkan tabel 6 hasil analisis Wilcoxon setelah diberikan perlakuan dengan teknik token economy menunjukkan minat belajar siswa berada pada kategori tinggi atau baik. Hal tersebut menunjukkan bahwa ada perbedaan yang signifikan antara kelompok pretest dengan kelompok posttest dengan nilai masing-masing nilai Asymp. sig. (2-tailed) probabilitas 0.001 pada taraf signifikansi nilai 0.05 $(\mathrm{p}<0.05)$, yang berarti dapat disimpulkan bahwa teknik token economy melalui layanan bimbingan kelompok untuk meningkatkan minat belajar siswa kelas VIII SMP Negeri 5 Wangi-wangi yang dilakukan berhasil secara signifikan atau efektif untuk dilakukan.

Layanan bimbingan kelompok dengan teknik token economy diberikan sebanyak delapan kali pertemuan. Setiap pertemuan peneliti memberikan materi yang sesuai dengan aspek minat belajar dan kegiatan diskusi kelompok dalam hal ini siswa diharapkan dapat meningkatkan minat belajar (teknik token economy) melalui layanan bimbingan kelompok. 
Pada proses pengamatan dalam pemberian layanan, setiap pertemuan siswa mengalami perubahan sikap dan perilaku yang baik seperti siswa mulai menampakkan perasaan senangnya, mulai terdorong untuk melakukan aktivitas belajar, memberikan perhatian dalam proses belajar, dan siswa mulai terlibat dan aktif dalam pembelajaran. Berikut salah satu hasil pengamatan dengan pemberian token economy.

Berdasarkan hasil pengamatan setelah postest, siswa mulai menunjukkan minat belajar berdasarkan aspek-aspeknya atau indikatornya yaitu sebagai berikut:

1) Perasaan Senang

Setelah diberikan perlakuan melalui bimbingan kelompok teknik token economy, siswa mulai memiliki perasaan senang untuk mengikuti pelajaran. Hal tersebut tampak melalui perilaku siswa yaitu siswa terlihat lebih rileks dalam mengikuti bimbingan dan proses belajar di kelas dan tak terlihat keterpaksaan dalam mengikuti bimbingan dan proses belajar.

2) Ketertarikan Siswa

Setelah pemberian perlakuan dengan teknik token economy, siswa mulai menampakkan ketertarikan dirinya untuk mengikuti pelajaran disebabkan karena ada hal baru yang dilakukan oleh guru atau pun peneliti ketika memberikan bimbingan dan menyampaikan mata pelajaran.

3) Perhatian Siswa

Setelah penerapan teknik token economy, siswa mulai memiliki minat dalam mengikuti bimbingan dan proses belajar dalam hal ini siswa mulai memberikan perhatiannya dan guru ataupun peneliti memberikan hal-hal baru yang dapat menarik perhatian siswa.

4) Keterlibatan Siswa

Setelah penerapan teknik token economy, yang tampak adalah siswa terlibat dan aktif dalam proses belajar. Siswa mulai mengikuti bimbingan dan pelajaran dengan baik, dan ketika siswa benar-benar ingin tahu, siswa tak segan untuk bertanya ataupun diskusi bersama teman, ataupun guru.

Adapun ditinjau dari aspek-aspek siswa, sebelum dan setelah diberikan perlakuan juga mengalami perubahan yaitu berupa peningkatan minat belajar yang cukup baik atau dalam persentasi dikategorikan sedang. Dalam penerapan 
teknik token economy tanggung jawab keberhasilan konseling berada di tangan konseli (dalam penelitian ini adalah siswa yang menjadi sampel penelitian).

Erford (2016: 395) menyatakan bahwa "token economy adalah suatu bentuk reinforcement positif yang dalam prosesnya seorang siswa menerima suatu token ketika mereka memperlihatkan perilaku yang diinginkan". Token yang diterima kemudian ditukarkan diakumulasikan dalam jumlah tertentu, untuk kemudian ditukarkan dengan penguat (hadiah). Teknik token economy dapat diimplementasikan dengan tingkat keberhasilan tertentu untuk semua subyek yang perilakunya layak untuk dimodifikasi. Erford (2016: 402) juga menyatakan beberapa kelebihan dari token economy yaitu "token economy dapat digunakan untuk memperbaiki manajemen kelas, dan juga dapat digunakan untuk meningkatkan partisipasi kelas". Berdasarkan pendapat tersebut dapat disimpulkan bahwa selain memodifikasi perilaku, token economy juga dapat digunakan untuk peningkatan pembelajaran di kelas yaitu manajemen dan partisipasi kelas.

Setelah penerapan teknik Token economy untuk meningkatkan minat belajar siswa kelas VIII SMP Negeri 5
Wangi-wangi, siswa mulai menumbuhkan minat belajarnya dengan bekerja sama dengan guru. Saat guru memberikan sesuatu yang baru, yang dapat menarik perhatian siswa, membuat siswa nyaman dan senang saat mengikuti pelajaran, dan melibatkan siswa dan aktif dalam proses belajar. Dengan penerapan teknik token economy, ada hal baru yang belum pernah dirasakan oleh siswa, sehingga menumbuhkan dan meningkatkan minat belajar siswa dalam mengikuti bimbingan dan proses belajar.

Berdasarkan uraian tersebut di atas menunjukkan bahwa ada perubahan yang signifikan yaitu peningkatan minat belajar siswa pada semua aspek yang diterapkan. Meskipun demikian, hendaknya perlu dikembangkan lagi terkait dengan minat belajar siswa menurut beberapa teori lain. Maka dapat disimpulkan bahwa teknik token economy melalui layanan bimbingan kelompok efektif untuk meningkatkan minat belajar siswa kelas VIII SMP Negeri 5 Wangiwangi

\section{PENUTUP}

Berdasarkan hasil penelitian ini, dapat disimpulkan bahwa secara umum Berdasarkan hasil penelitian dapat disimpulkan bahwa Teknik token economy melalui layanan bimbingan kelompok untuk meningkatkan minat 
belajar siswa, efektif untuk dilakukan, karena siswa telah mampu menumbuhkan dan mengembangkan minat belajarnya setelah diberikan perlakuan dan kualitas layanan bimbingan dan konseling serta teknik yang diterapkan. Melalui teknik token economy dengan 8 kali pertemuan telah mampu meningkatkan minat belajar siswa secara persentasi secara menyeluruh dengan 14 sampel, 5 siswa atau $35.7 \%$ subyek dalam kategori sedang dan 9 siswa atau $64.3 \%$ subyek telah memiliki minat belajar yang baik atau tinggi. Peneliti juga menemukan bahwa siswa akan lebih aktif dengan pemberian reward (hadiah).

Bagi peneliti selanjutnya yang tertarik untuk meneliti minat belajar dan teknik token economy, untuk dapat menguji variabel lain yang lebih signifikan seperti kedisiplinan, motivasi belajar dan menggunakan teknik konseling yang lebih efektif.

\section{DAFTAR PUSTAKA}

Astuti, Siwi Puji. 2015. Pengaruh Kemampuan Awal dan Minat Belajar Terhadap Prestasu Belajar Fisika. Jurnal Formatif, 5 (1): 6875 .

Azwar, Syarifuddin. 2012. Penyusunan Skala Psikologi. Yogyakarta: Pustaka Pelajar

Basir, I \& Astutik, S. 2018. Bimbingan dan Konseling Islam dengan Teknik Token Economy dalam Membentuk Disiplin Sholat pada Anak di
Sidoarjo. Jurnal Bimbingan dan Konseling Islam 8 (1) 86-100.

Erford, Bradley T. 2016. 40 Teknik yang Harus Diketahuo Setiap Konselor Edisi Kedua. Helly Prajitno \& Sri Mulyantimin. Yogyakarta: Pustaka Pelajar

Marsilia \& Mahmudi I. 2015. Perubahan Perilaku Prokrastinasi Akademik Melalui Konseling Kelompok Dengan Teknik Token Economy Pada Siswa Kelas X TP SMKN 1 Wonoasri Kabupaten Madiun. Counselia: Jurnal Bimbingan dan Konseling, 5 (2), 40-57.

Muh. Chotim, dkk. 2013. Penerapan Teknik Token economy Untuk Meningkatkan Kemandirian Anak TK Kartika IV-21 Madiun. Counselia: Jurnal Bimbingan dan Konseling, 3 (2), 33-42.

Myda Aprilia Hapsari. 2017. Keefektifan Teknik Token economy Untuk Meningkatkan Student Engagement pada Siswa Kelas IV SDN Plalalangan Kota Semarang. Skripsi. Tidak diterbitkan. Universitas Negeri Semarang.

Rahmawati Nimas. 2015. Token economy Sebagai Upaya Meningkatkan Kedisiplinan Siswa Pada Mata Pelajaran Matematika Kelas II SD Baturetno. Skripsi: Tidak diterbitkan. Yogyakarta: Universitas Negeri Yogyakarta

Riwahyudin, A. 2015. Pengaruh Sikap Siswa dan Minat Belajar Siswa Terhadap Hasil Belajar Siswa IPA Kelas V SD Di Kabupaten Lamandau. Jurnal Pendidikan Dasar, 6 (1), 11-23.

Pramana, Hengky W. 2012. Aplikasi Inventory Berbasis Access 2011. 
Jakarta: PT Elex Media Komputindo

Prahmadita, A.D. 2014. Faktor-faktor Yang Mempengaruhi Minat Siswa Untuk Mengikuti Ekstrakurikuler Drumband di SMP Negeri 1 Sleman. Fakultas Bahasa dan Seni.
Yogyakarta: Universitas Negeri Yogyakarta.

http://eprints.uny.ac.id/17679/1/Aul ia\%20Devi\%20Prahmadita\%20082 08241012.pdf

Slameto. 2010. Belajar dan Faktor yang Mempengaruhinya. Jakarta: Rineka Cipta. 